\title{
Genetic Analysis of Field Isolates of Infectious Bursal Disease Virus in Iraqi Farms
}

\author{
Rawaa S Jumaa ${ }^{1}$, Aida B Allawi ${ }^{1}$, and Rebah N Jabbar ${ }^{2}$ \\ ${ }^{1}$ Microbiology Department, College of Veterinary Medicine, University of Baghdad, Iraq, ${ }^{2}$ Biotechnology \\ Research Center, Al-Nahrian University, Baghdad, Iraq
}

\begin{abstract}
Sixty samples of bursa of Fabricius were collected from broiler chickens suspected to be infected with infectious bursal disease virus (IBDV) in different areas of Iraq for molecular evaluation. The extracted nucleic acid was amplified using reverse transcriptase polymerase chain reaction (RT-PCR) targeting genes of segment A ( $V p 2, V p 3, V p 4$ and $V p 5$ genes) and segment B (VP1 genes). The products of amplification were sent to Korea for sequencing using Sanger method. The sequencing analysis of the IBDV from the Iraqi isolates revealed that each gene had different transition and transversion (nonsense and missense of point mutation) compared to reference genes. The phylogenetic tree analysis showed that the VP2 of segment A of the Iraqi samples was similar to that of an Egyptian strain with 96\%similarity, the polypeptide VP2-3-4 of segment A of the Iraqi samples was similar to those of a Chinese strain with $99 \%$ similarity and the VP5 of segment A was similar to that of Chinese strain with $99 \%$ similarity. However, the phylogenetic tree analysis showed that the VP1 of segment B had $95 \%$ similarity with that of a Chinese strain.
\end{abstract}

\section{Keywords: IBDV, Conventional RT-PCR, VP genes, Sequence analysis, Iraq}

\section{Introduction}

Infectious bursal disease virus (IBDV) is a double stranded RNA (dsRNA) virus, which belongs to Avibirnavirus genus in the Birnaviridae family. The virus has two segmented genome segments, A (large segment) and B (small segment), within a nonenveloped and icosahedral capsid. IBDV is the causative agent of an immunosuppressive disease in young chickens (1). Each segment encodes viral proteins $(V P)$, segment A encodes $V P 2, V P 3, V P 4$, and $V P 5$ and segment $\mathrm{B}$ encodes $V P 1$. Each viral protein has specific functions in the viral replication. The VP1is RNA-dependent RNA polymerase, which is responsible for the genome replication, transcription (2), and maybe the translation of viral proteins (3). The VP2 is the major structural viral protein that builds the viral capsid (4) and has an antigenic domain responsible

Correspondance: rawaa.saladdin@covm.uobaghdad.edu.iq, Department of Micrbiology, College of Veterinary Medicine, Unicersity of Baghdad, Iraq. Recieived: 19 November 2019, Accepted: 19 December 2019, Published: 28 June 2020.

This article is an open access article under the terms and conditions of the Creative Commons Attribution License (CC BY 04) https://crerativecommons.org/licenses/by/4.0). DOI: https://doi.org/10.30539/ijvm.v44i1.931 for inducing the secretion of neutralization antibodies (5). The VP2 and VP3 together play an important role in the morphogenesis and encapsidation of the viral genome (6). The VP4 is a viral protease (7) that affects post-translational cleavage of the polyproteins $(V P 2-V P 4-V P 3)$ and takes part in the maturation of the $V P 2$ peptide (8). $V P 5$ is a non-structural protein that is responsible for releasing virus progeny from infected cells both through the non-lytic mechanism during the early phase of infection (9) and the activation of cell apoptosis in the later stages by interacting with mitochondrial ionic channels (VDAC2) (10). Thereby the nature of segmented genome of the virus has natural reassortment whereby an exchange of the genetic material can occur if many viruses infect one cell at the same time. This natural reassortment of IBDV has been reported in several countries such as Asia (11), South America (12), North America (13), Africa (14), and Europe (15). The IBDV has serotype 1 and serotype II. The serotype II is nonpathogenic to chicken, but the serotype $I$ is pathogenic and has several strains according to the virulence of this strain. The strains of serotype I, including the very virulent of IBDV (vvIBDV), are the most pathogenic and can cause mortality up to $100 \%$ in specific-pathogen-free 
chickens (SPF). Classical strain and variant strain are less virulent, but they are immunosuppressive (16).

In Iraq, IBDV is a major health problem in chicken and causes economic losses in birds through immunosuppression and susceptibility to other infections. Many studies confirmed the presence of this virus in Iraq in which the virus was isolated by Yousif and Nawzad (17) who diagnosed this virus from infected broilers in Sulaimania, in north region of Iraq, using PCR technique (18). Also, IBDV field strains were characterized in commercial broiler flocks in Tikrit city using RT-PCR to detect vvIBDV using a specific primer set (19) and the (20) who revealed the IBDV has antigenic drift. This means that the virus possesses antigenic variation in the $V P 2$ (hydrophilic region) that preserves the neutralizing domine which is responsible for binding with monoclonal antibodies and this revealed that the vaccine should be prepared from a local strain, but the amplification of both genes ( VP1 and $V P 2$ ) sequencing is still not studied. Therefore, the current study was designated to investigation the virulence of field isolates of IBDV by sequencing of both genes which might responsible for virulence of field isolates that found in Iraq.
Materials and Methods

\section{Collection of Samples}

Bursa of Fabricius samples were collected from 60 broiler chickens at age 25-35 days suspected to be infected with Gumboro disease after postmortem examination. These specimens were collected from different areas of Iraq including Baghdad province (20 samples), Karbala province (5 samples), Diyala province (Baqubah) (3 samples), Wasit province (Kut) (10 samples), Al-Anbar province (Ramadi) (3 samples), Babil province (Hillah) (12 samples), Salah Aldin province (4 samples), and Al-Basrah province (3 samples). These tissues were put in test tubes and preserved at $-20{ }^{\circ} \mathrm{C}$ till use.

\section{Primers Used in Conventional PCR}

The primers used for sequencing the viral genome of avian infectious bursal disease virus were designed by using the National Center for Biotechnology Information (NCBI) software. Three pairs of primers were used to amplify different regions of segment B of the virus, and four pairs of primers were used to amplify genes of segment A $(V P 2, V P 3, V P 4$, and $V P 5)$. The primers are listed in Table 1.

Table 1. Primers designed for $V P 1, V P 2$ genes and segment A and B of IBDV

\begin{tabular}{|c|c|c|c|c|c|}
\hline No. & Segment & Primer name & & Product size & Sequence $\left(5^{\prime}-3^{\prime}\right)$ \\
\hline \multirow[t]{6}{*}{1} & Segment B & B1 & Forward & 606 & 5'-GTCTCAAGTCCAAGGTCGGG-3' \\
\hline & & & Reverse & & 5'-CGGAAGTCGACTGAACTGCT-3' \\
\hline & & B2 & Forward & 533 & 5'-CATGCGGGCTTTTGTTTCCA-3' \\
\hline & & & Reverse & & 5'-GATGAACGTGGCTGCATTCC-3' \\
\hline & & B3 & Forward & 940 & 5'-CGGCGACCCAATGTTCAATC-3' \\
\hline & & & Reverse & & 5'-GAGTTTCTCGGCTTCTGCCT-3' \\
\hline \multirow[t]{8}{*}{2} & Segment A & A1 & Forward & 739 & 5'-GAGCCTAGCAGTGACGATCC-3' \\
\hline & & & Reverse & & 5'-GCTGTTCAGTGCTTTGGGTG-3' \\
\hline & & A2 & Forward & 568 & 5'-CACCCAAAGCACTGAACAGC-3' \\
\hline & & & Reverse & & 5'-TTGAACTCTGATGCGGCCAT-3' \\
\hline & & A3 & Forward & 677 & 5'-ACTCCCTGGTGGCGTTTATG-3' \\
\hline & & & Reverse & & 5'-GGATCGTCACTGCTAGGCTC-3' \\
\hline & & A4 & Forward & 1000 & 5'-CGTCCCGTCACACTAGTAGC-3' \\
\hline & & & Reverse & & 5'-AAGCATTGAGGGCTCCTGTC-3' \\
\hline
\end{tabular}


Prior to running conventional reverse transcriptase PCR (RT-PCR), total RNA was extracted using total RNA mini extraction kit (Gene aid Corporation) from the specimens of bursa of Fabricius. Then EnergicScript ${ }^{\circledR}$ first strand cDNA synthesis kit was used to convert the viral RNA by reverse transcriptase into cDNA. This reaction involved the addition of $1 \mu \mathrm{l}$ of RTase, $1 \mu \mathrm{l}$ of random primers, $3 \mu \mathrm{l}$ of DEPC- $\mathrm{ddH}_{2} \mathrm{O}, 10 \mu \mathrm{l}$ of $2 \mathrm{x}$ RT buffer, and $5 \mu$ of RNA sample. The PCR reaction tube (total reaction volume of $25 \mu \mathrm{l}$ ) composed of $5 \mu \mathrm{l}$ of cDNA sample, $12.5 \mu \mathrm{l}$ of Go Taq® Green Master Mix (Promega), $1 \mu$ of each of forward and reverse primers as well as $5.5 \mu \mathrm{l}$ of RNase-free water. The PCR conditions were one cycle for initial denaturation for 5 minutes at $94^{\circ} \mathrm{C}$, followed by 35 cycles of denaturation for 45 seconds at $95^{\circ} \mathrm{C}$, annealing for 30 seconds at $62^{\circ} \mathrm{C}$, extension for 45 seconds at $72^{\circ} \mathrm{C}$, extra extension for 10 minutes at $72^{\circ} \mathrm{C}$, and holding at $4^{\circ} \mathrm{C}$. To confirm PCR products, agarose gel $(2 \%)$ was made using Tris-Borate EDTA (TBE) buffer (Biotech). Then, the cDNA samples along with DNA ladder (100-1500 bp) were loaded, and the electrophoresis was run at $10 \mathrm{~V} / \mathrm{cm}$ for $40 \mathrm{~min}$ to separate the cDNA products already stained with Ethidium bromide (Biotech). Eventually, the cDNA bands were visualized using UV transilluminator.

\section{Sequencing}

The products of amplification of the viral cDNA were sent to Korea (Macrogen) for sequencing using Sanger method. Later, both BLAST (http://blast.ncbi.nlm.nih.gov) and Mega 6 software were used to analyze the obtained nucleotide sequences.

\section{Bioinformatics Analysis of the VP Proteins}

Raptorx software was used to analyze VP proteins of the viral isolates.

\section{Phylogenetic Analysis}

The phylogenetic relationships of the IBDV isolates were analyzed using the Mega 6 software.

\section{Results}

\section{Molecular Detection of the IBDV}

The gel electrophoreses revealed bands of the expected sizes of the genes amplified by conventional PCR (Figure 1).

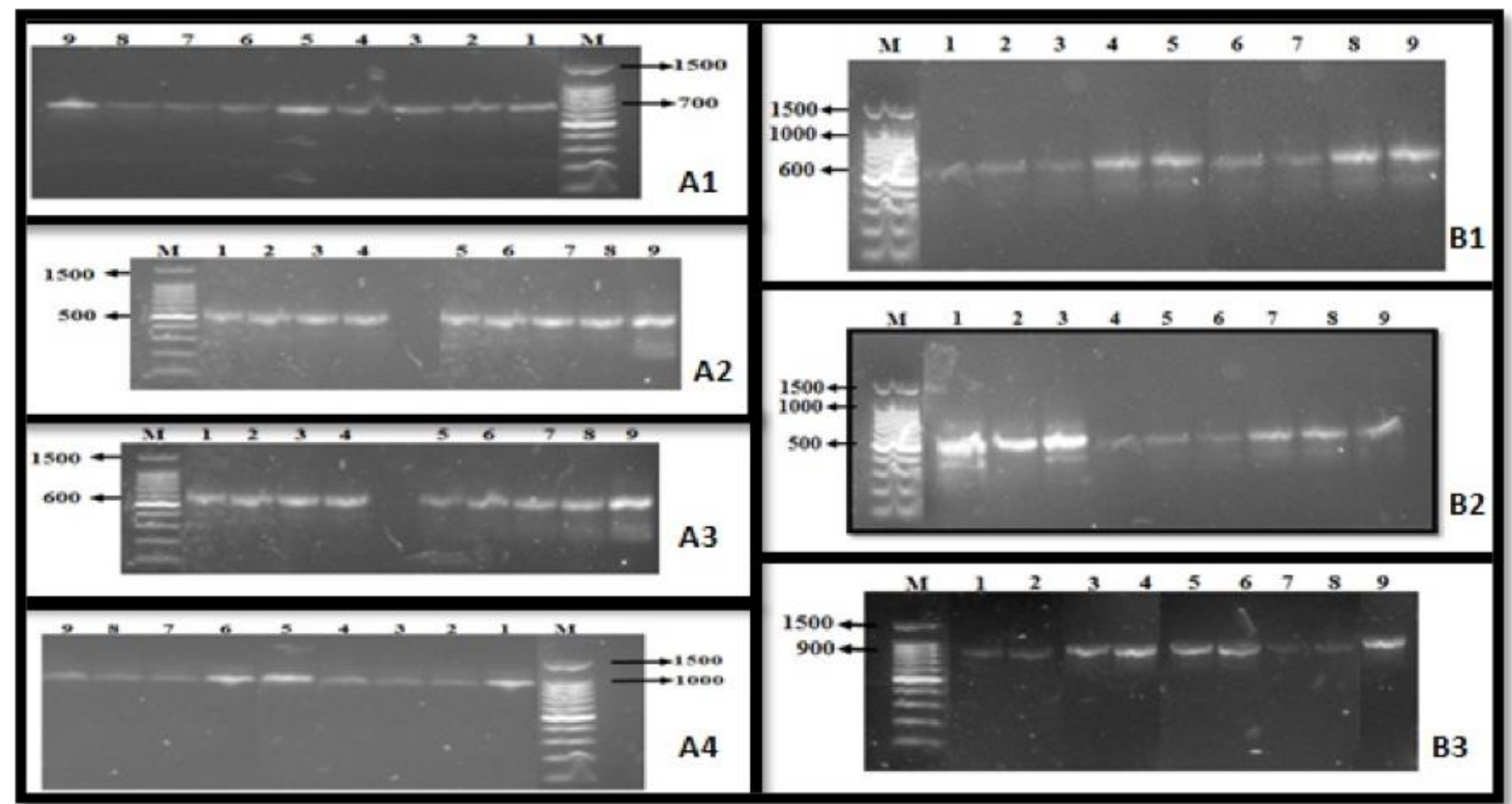

Figure 1. Agarose gel electrophoresis shows bands of the expected sizes of the amplified segment A $(A 1,2,3,4)$ and segment $B(B 1,2,3)$. Lane $M=$ Ladder, Lane 1 and 2= samples from Baghdad, Lane 3= samples from Karbala, Lane 4= samples from Diyala, Lane 5= samples from Wasit, Lane 6= samples from Al-Anbar, Lane 7= samples from Babylon, Lane 8= samples from Saladin, Lane 9= samples from Basrah 


\section{Sequence Analysis of Segment A}

Sequence analysis of PCR products obtained from the $V P 2$ gene showed that three out of nine PCR amplicons of the $V P 2$ gene amplified using primer A1 showed nucleotide changes, and two out of nine belong to A2 gene were showed positive sequence for VP5 in segment A. But the A3 had two out of nine PCR product positive for VP2-3-4 of segment $A$ and the A4 gene had two out nine of PCR product positive for $V P 2$.
The sequence analysis revealed the presence of changes in nucleotide sequences in different regions of the gene compared to the known reference gene sequences of the IBDV. There was either transition or transversion (missense or nonsense). These nucleotide changes made the Iraqi IBDV a unique isolate in the region from which it was isolated. These changes are listed as numbers in Table 2.

Table 2. Nucleotide changes of the sequences amplified from segment $A$

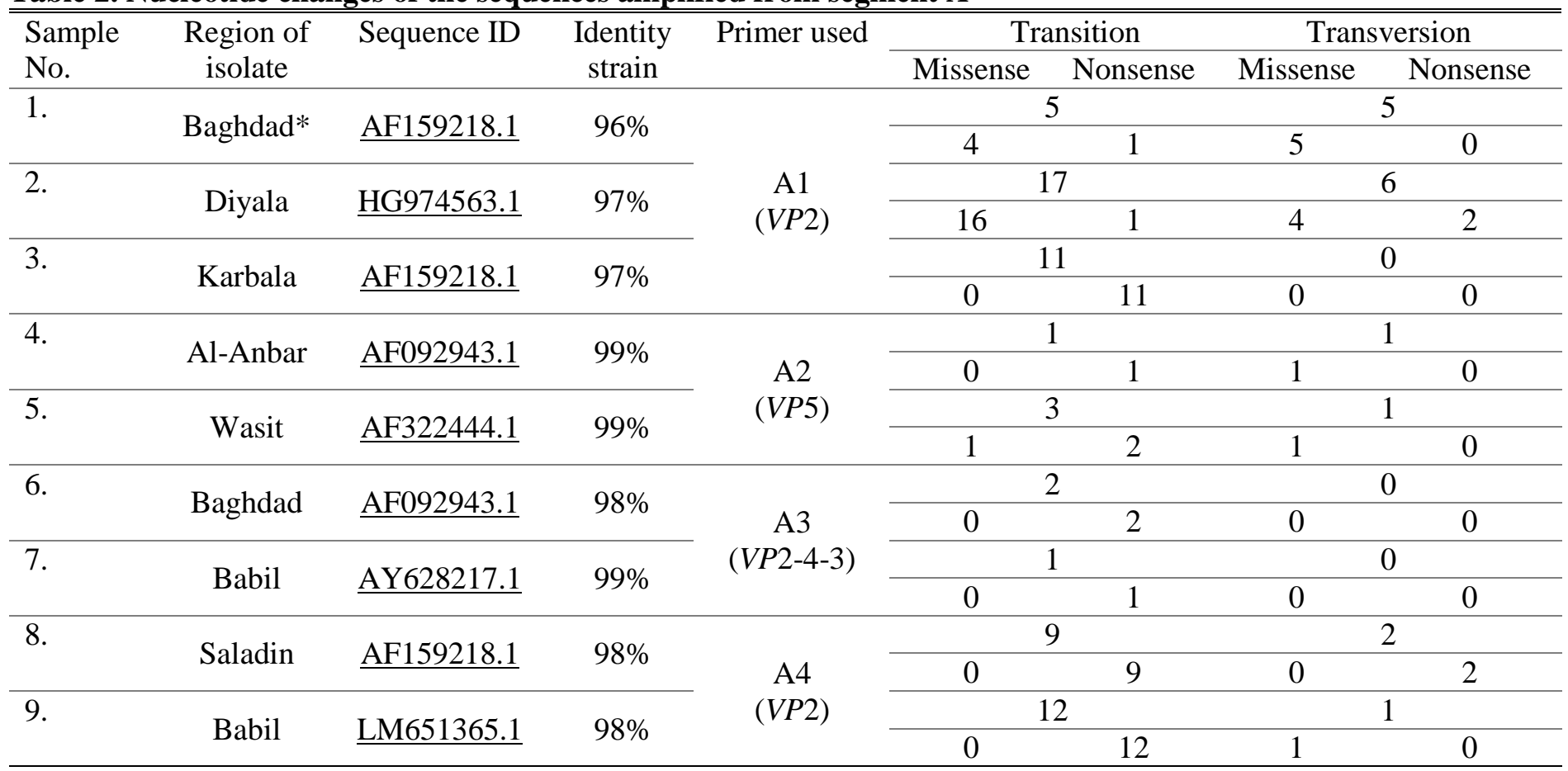

*This sample was submitted to NCBI under the accession number MK507831.1

\section{Sequence Analysis of Segment B}

Sequence analysis for the PCR products of the VP1 gene showed that two out of nine PCR amplicons and six out of nine belonged to B2 gene showed positive sequence. But the B3 had 4 out of 9 PCR products were positive the sequence analysis which revealed the presence of change in different regions of nucleotide sequences with different percentages compared to other global known IBDV. There was either transition or transversion (missense or nonsense). These changes in nucleotide sequences made the Iraqi IBDV a unique isolate in the region from which it was isolated. These changes are listed as numbers in Table 3.

\section{VP Protein Characteristics of the IBDV}

Results of bioinformatics analysis of the secondary structure of VP2, VP2-3-4, and VP5 in segment A and $V P 1$ in segment $\mathrm{B}$ are shown in Figure 2. These structures were found to be composed of alphahelix, beta-sheet, and coiled coil. The viral proteins revealed a ribbon diagram of protein structure included amino acids. 
Table 3. Nucleotide changes of the sequences amplified from different regions of the VP1gene on segment $B$

\begin{tabular}{|c|c|c|c|c|c|c|c|c|}
\hline \multirow{2}{*}{$\begin{array}{c}\text { Sample } \\
\text { No. }\end{array}$} & \multirow{2}{*}{$\begin{array}{l}\text { Region of } \\
\text { isolate }\end{array}$} & \multirow[t]{2}{*}{ Sequence ID } & \multirow{2}{*}{$\begin{array}{l}\text { Identity } \\
\text { strain }\end{array}$} & \multirow{2}{*}{$\begin{array}{l}\text { Primer } \\
\text { used }\end{array}$} & \multicolumn{2}{|c|}{ Transition } & \multicolumn{2}{|c|}{ Transversion } \\
\hline & & & & & Missense & Nonsense & Missense & Nonsense \\
\hline \multirow[t]{2}{*}{1.} & Baghdad & KU234529.1 & $94 \%$ & \multirow{4}{*}{$\begin{array}{c}\mathrm{B} 1 \\
(V P 1)\end{array}$} & \multicolumn{2}{|c|}{15} & \multicolumn{2}{|c|}{4} \\
\hline & & & & & 0 & 15 & 1 & 3 \\
\hline \multirow[t]{2}{*}{2.} & Wasit & EU595678.1 & $95 \%$ & & \multicolumn{2}{|c|}{10} & \multicolumn{2}{|c|}{8} \\
\hline & & & & & 1 & 9 & 7 & 1 \\
\hline \multirow[t]{2}{*}{3.} & Babil & EU595676.1 & $94 \%$ & \multirow{13}{*}{$\begin{array}{c}\mathrm{B} 2 \\
(V P 1)\end{array}$} & \multicolumn{2}{|c|}{11} & \multicolumn{2}{|c|}{8} \\
\hline & & & & & 0 & 11 & 3 & 5 \\
\hline \multirow[t]{2}{*}{4.} & Saladin & EU595676.1 & $97 \%$ & & \multicolumn{2}{|c|}{5} & \multicolumn{2}{|c|}{0} \\
\hline & & & & & 0 & 5 & 0 & 0 \\
\hline \multirow[t]{2}{*}{5.} & Al-Anbar & KU234529.1 & $94 \%$ & & \multicolumn{2}{|c|}{11} & \multicolumn{2}{|c|}{8} \\
\hline & & & & & 1 & 10 & 5 & 3 \\
\hline \multirow[t]{2}{*}{6.} & Diyala & KU234529.1 & $93 \%$ & & \multicolumn{2}{|c|}{9} & \multicolumn{2}{|c|}{5} \\
\hline & & & & & 4 & 5 & 4 & 1 \\
\hline \multirow[t]{2}{*}{7.} & Karbala & EU595678.1 & $98 \%$ & & \multicolumn{2}{|c|}{2} & \multicolumn{2}{|c|}{2} \\
\hline & & & & & 1 & 1 & 1 & 1 \\
\hline \multirow[t]{2}{*}{8.} & Al-basrah & $\underline{\text { EU595677.1 }}$ & $95 \%$ & & \multicolumn{2}{|c|}{8} & & \\
\hline & & & & & 0 & 8 & 0 & 4 \\
\hline 9. & Al-Basrah & $\underline{\mathrm{AJ} 295026.1}$ & $99 \%$ & & & & & \\
\hline & & & & $(V P 1)$ & 0 & 3 & 0 & 0 \\
\hline 10. & Wasit & AJ295026.1 & $99 \%$ & & & & & \\
\hline & & & & & 0 & 2 & 0 & 0 \\
\hline 11. & Saladin & MF969108.1 & $99 \%$ & & & & & \\
\hline & & & & & 1 & 1 & 2 & 0 \\
\hline 12. & Baghdad* & MF969108.1 & $99 \%$ & & & & & \\
\hline & & & & & 0 & 1 & 0 & 0 \\
\hline
\end{tabular}

*This sample was submitted to NCBI under the accession number MK507832.1

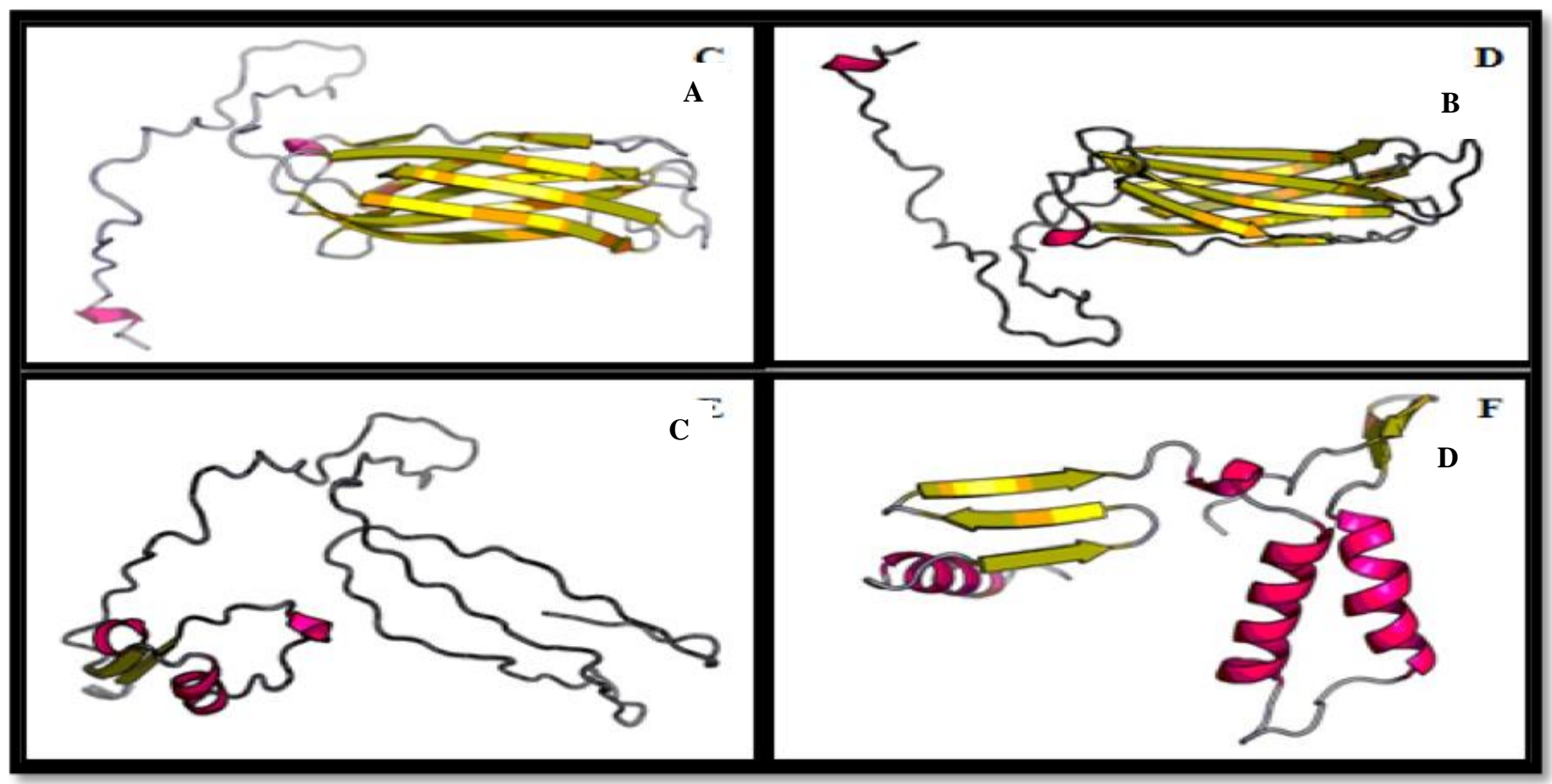

Figure 2. VP protein analysis: A) $V P 2$ in segment $A, B) V P 2-3-4$ in segment $A, C) V P 5$ in segment $A$ and D) $V P 1$ in segment B for IBDV. Raptorx software was used for drawing structure protein (alpha-helixes, beta-sheets, and coils) of amino acid 


\section{Phylogenetic Tree Analysis}

The phylogenetic analysis showed that five isolates having $V P 2$ were similar to the Egyptian strain with an identity of $96 \%$ and a French strain with an identity of $95 \%$ (Figure 3). But the phylogenetic analysis of genes $V P 2, V P 3, V P 4$, and $V P 5$ showed that two isolates were similar to a Chinese strain with an identity of 99\%, and another Chinese strain with an identity of $98 \%$. An Australian strain was identical with 99\% to VP5 (Figures 4 and 5). Moreover, the phylogenetic analysis of segment B $(V P 1)$ revealed that six isolates were similar to the Chinese strain with an identity of $95 \%$ and German strain with an identity of $95 \%$ (Figure 6).

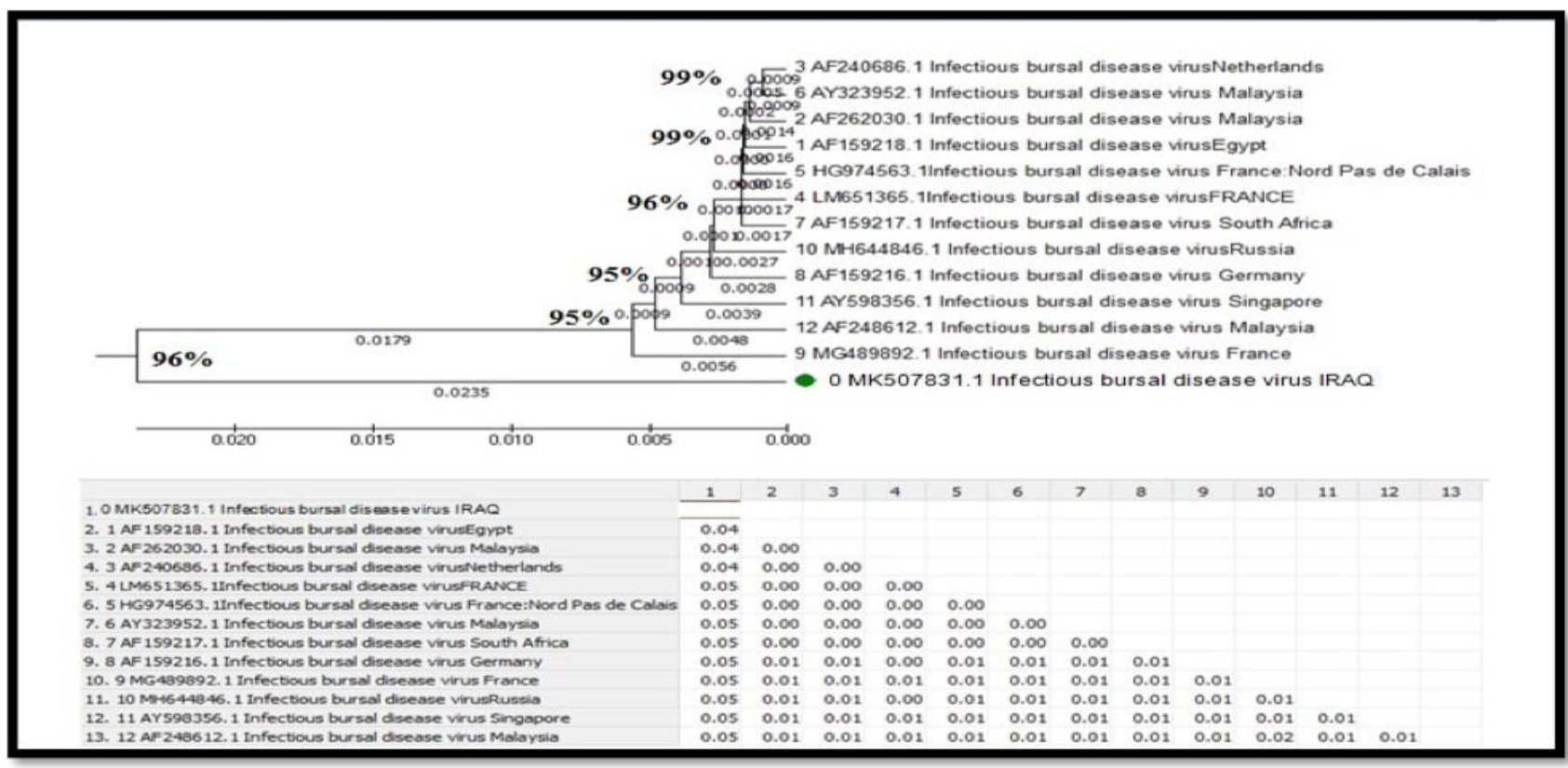

Figure 3. Phylogenetic tree of the VP2 gene of an Iraqi isolates submitted to NCBI under the accession number MK507831.1

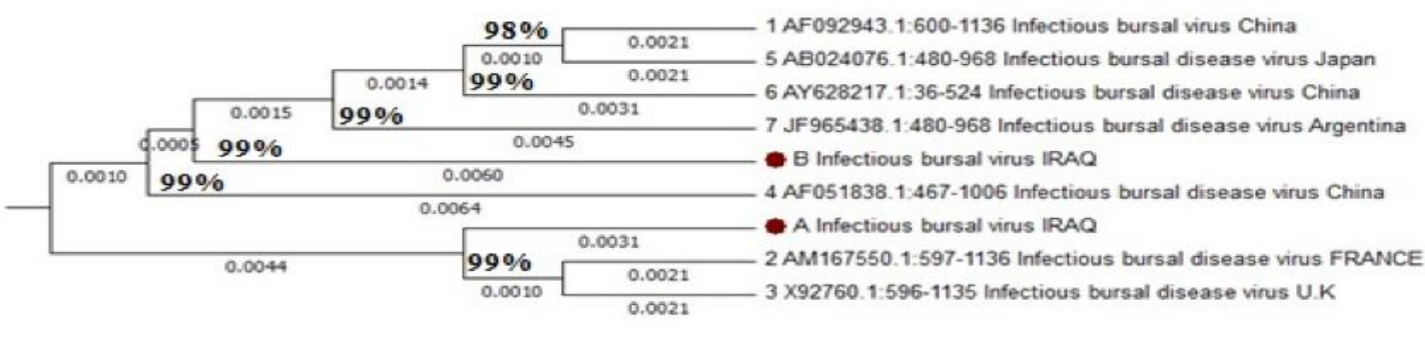

\begin{tabular}{l}
\hline 0.007 a.006 0.005 0.004 a.003 a.002 0.001 \\
1. A Infectious bursal virus IRAQ \\
2. B Infectious bursal virus IRAQ \\
3. 1 AF092943.1:600-1136 Infectious bursal virus China \\
4. 2 AM 167550. 1:597-1136 Infectious bursal disease virus FRANCE \\
5. 3 X92760. 1:596-1135 Infectious bursal disease virus U.K \\
6. 4 AF051838. 1:467-1006 Infectious bursal disease virus China \\
7. 5 AB024076.1:480-968 Infectious bursal disease virus Japan \\
8. 6 AY628217.1:36-524 Infectious bursal disease virus China \\
9. 7 JF965438.1:480-968 Infectious bursal disease virus Argentina
\end{tabular}

\begin{tabular}{|l|lllllll|l|}
\hline 1 & 2 & 3 & 4 & 5 & 6 & 7 & 8 & 9 \\
\hline & & & & & & & & \\
\hline 0.02 & & & & & & & \\
0.01 & 0.01 & & & & & & \\
0.00 & 0.02 & 0.01 & & & & & \\
0.01 & 0.02 & 0.01 & 0.00 & & & & \\
0.02 & 0.02 & 0.01 & 0.02 & 0.01 & & & & \\
0.01 & 0.01 & 0.00 & 0.01 & 0.01 & 0.01 & & & \\
0.02 & 0.01 & 0.01 & 0.02 & 0.01 & 0.01 & 0.01 & & \\
0.01 & 0.01 & 0.01 & 0.01 & 0.01 & 0.01 & 0.01 & 0.01 & \\
\hline
\end{tabular}

Figure 4. Phylogenetic tree of VP2-3-4 of two Iraqi isolates 


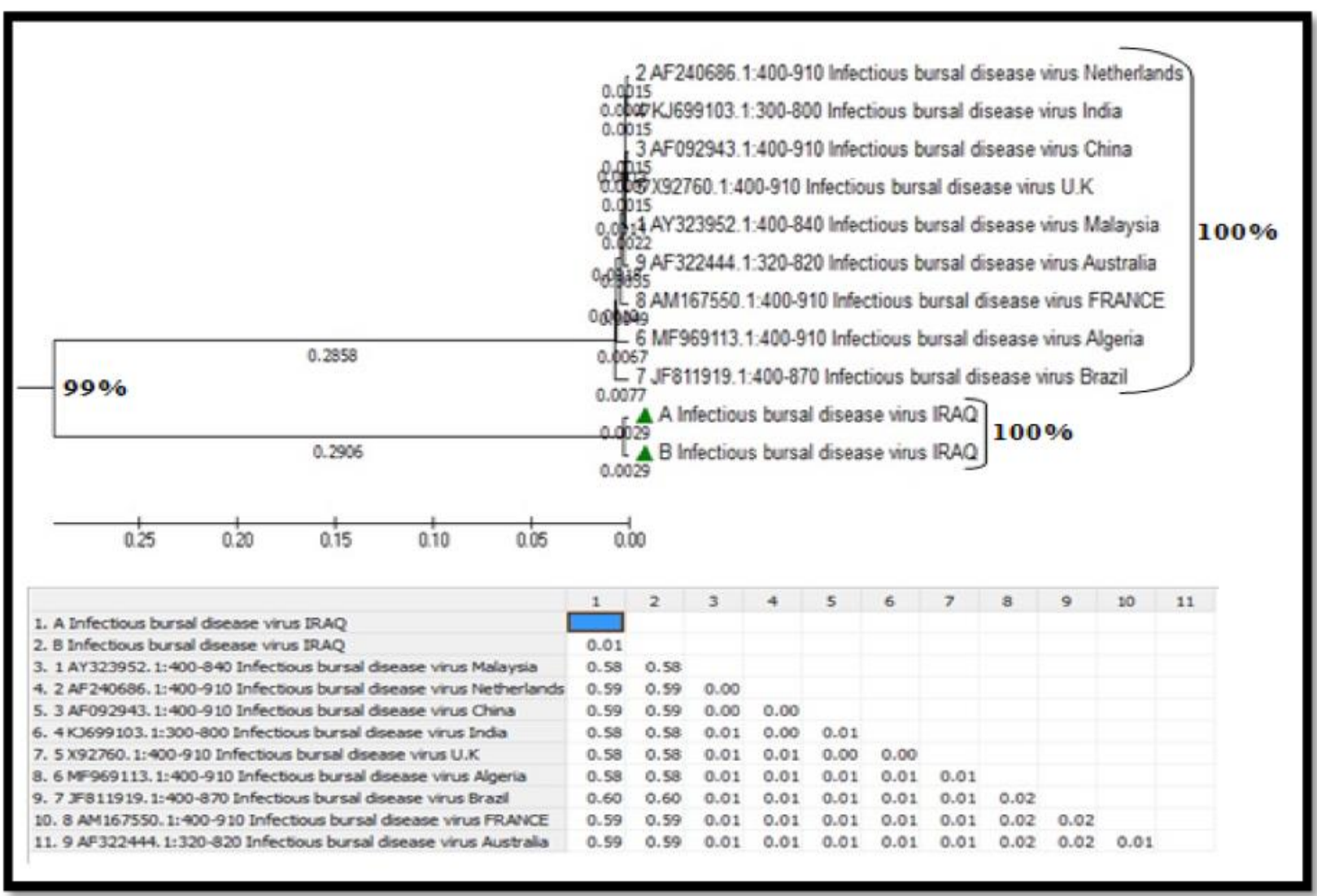

Figure 5. Phylogenetic tree of VP5 gene of two Iraqi isolates

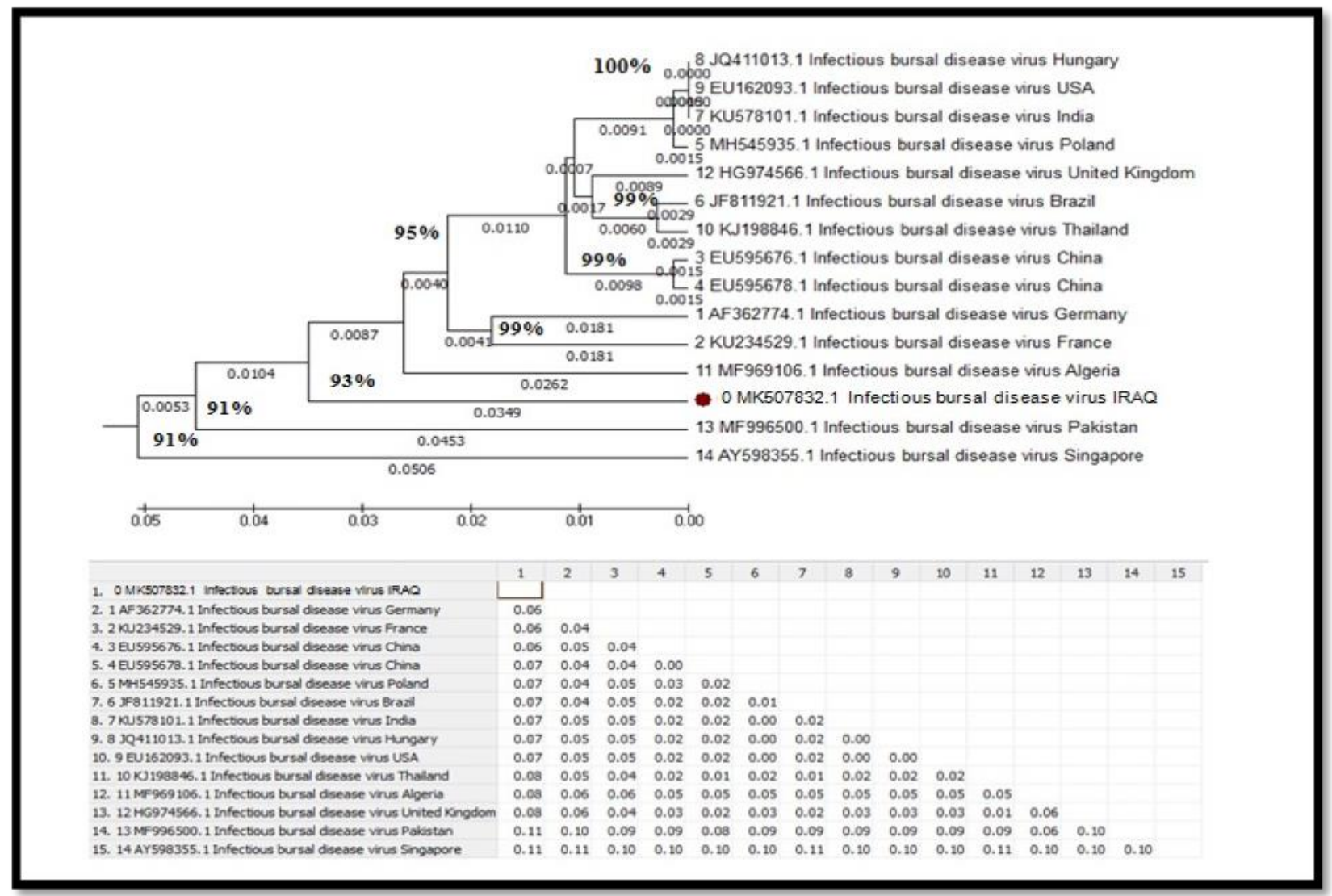

Figure 6. Phylogenetic tree VP1 gene of an Iraqi isolate submitted to NCBI under the accession number MK507832.1 


\section{Discussion}

Infectious bursal disease (IBD) or (Gumboro disease) is a highly contagious disease of young chickens caused by infectious bursal disease virus (IBDV) (21). The sequencing analysis of PCR products for segment $\mathrm{A}$ and segment $\mathrm{B}$ showed changes in different regions of nucleotide sequences with different percentages compared to other globally known IBDV. These results revealed the exchange of amino acid at different positions in segment A (VP2,VP2-3-4, and VP5) and segment B $(V P 1)$ may be leading to changing of viral antigenic properties or viral replication and viral characteristics strains. These results are in agreement with $(22,23)$ who revealed the mutation at different positions leading to exchange of amino acid in hydrophilic part or hydrophobic part of $V P 2$, therefore, resulted in the vvIBDV has tolerated antigenic properties or resulted in lack of a neutralizing monoclonal antibody to vvIBDV strains.

The results of conformation of protein in sequencing analysis showed the secondary structure of protein consists of helical, $\beta$-sheet, and coil or ribbon model of IBDV proteins including segment $\mathrm{A}(V P 2, V P 2-3-4$, and VP5) and segment B (VP1). This conservation of secondary structure is an important parameter in the evaluation of the structural model of viral proteins. These were substitution mutations which either transition or transversion (nonsense or missense) that lead to change in amino acid sequence. The transition is a point mutation which changes the purine nucleotide to another purine nucleotide (Adenine to Guanine) or (Guanine to Adenine) or changes the pyrimidine nucleotide to another pyrimidine nucleotide (Cytosine to Thymine) or (Thymine to Cytosine) that means these changes (transition) are 2 out of 3 single nucleotide polymorphisms (24). The transversion is a point mutation which changes the purine (2 rings) nucleotide (Adenine or Guanine) into pyrimidine (1 ring) nucleotide (Thymine or Cytosine) and vice versa and occurs spontaneously (25). These point mutations that occurred within protein coding region of a gene and classified into nonsense mutations (synonymous substitutions) or missense mutation (non-synonymous substitutions). The nonsense mutations which do not alter amino acid sequence (silent mutation) while the missense mutations which alter amino acid sequences of a protein resulted in modified amino acid (26). The phylogenic tree analysis showed the VP1 of segment B of Iraqi detected strain under accession number (MK507832.1) was similar to the China strain (under accession number EU595676.1) with 95\% homology.

These results may be interference of wild type virus with laboratory adaptation virus (vaccine strain), therefore these viruses have competitive interference (heterologous interference) or autointerference (homologous interference) by either the first virus which competes with the second virus on components for its replication such as polymerase or translation factors or the first virus inhibit the multiplication of the second virus by destroying viral receptors. These results are consistent with those of (27) who revealed the attenuation of very virulent IBDV was due to multigenic mutations and competitive replication during in vitro and in vivo serial passages.

Moreover, the $V P 2$ of segment A of Iraqi detected strain under accession number (MK507831.1) was similar to the Egypt strain (under accession number AF159218.1) with 96\% homology. These results are due to antigenic drift in inside or outside of hydrophilic region and hydrophobic region of $V P 2$ that leads to some sites to become more stable and others less stable. Also, the mutations of VP2 are responsible for viral antigenicity, pathogenicity, and tissue tropism as reported by $(23,28)$.

The VP2-3-4 of segment A of two Iraqi detected strains were closely related to the Chinese strain (under accession number AY628217.1) both with $99 \%$ homology and the VP5 of segment A of two Iraqi detected strains were showed a high nucleotide homology to the Chinses strain (under accession number AF692943.1) both with 99\%. The shared $99 \%$ of nucleotide identity with these strains may be due to recombination event within segment A between wild type virus and attenuation virus or vaccine strain of IBDV. These results are consistent with (29) who reported that the full length of VP24-3 contained a unique residue within VP2 and the substitution at some position may influence polyprotein cleavage efficiency and/or protease activity. Additionally, the author found that the VP5 is not required for viral replication and infection but plays an important role in the release of viral progeny from infected cells.

The results of IBDV sequencing analysis, protein conformation, and phylogenetic tree may indicate that reassortment of IBDV or antigenic drift of the virus. The reassortment is a mixing of the genetic materials that occurs when two different strains of a 
similar virus are infecting the same cell of a single host therefore it results in a new strain that will share properties of parental virus. The reassortment is responsible for the genetic shift in segmented RNA viruses that confer the phenotypic change for new viruses which means to form a new subtype having a mixture of the surface antigens of the two or more original strains (5). The results are in agreement with (16) who reported that the virulence of IBDV contributed to both segment $\mathrm{A}$ and $\mathrm{B}$ due to the reassortment IBDV. The reassortment is one of the mechanisms of genetic diversity characteristic of viruses with segmented genomes and the shuffling of the segment of viral genome was originating from two parental strains with distinct patho-types (very virulent and classical cell culture adapted) also investigate the very virulent/attenuated reassortment that has hold over high virulence.

But the antigenic drift is an accumulation of mutation (point mutation) within subtype that confer new stain has of virus particles cannot be inhibited by antibodies that targeted previous strains. This mechanism occurs in RNA viruses due to RNA polymerase has no proofreading mechanisms (not error correcting process) and this mechanism allows the new virus has able to escape from host immune system due to mutations occur in viral surface proteins. The present results are in agreement with (20) who found that the IBDV has antigenic drift that means the virus possesses antigenic variation in the VP2 hyper-variable domine (hydrophilic region) that preserved the neutralizing domine which responsible for binding with monoclonal antibodies and revealed the vaccine should be prepared from the local strain. Therefore, these results indicate that the trading of infected birds or using trading live attenuated vaccines lead to the emergence of very virulent IBDV in Iraqi farms.

\section{References}

1. Eterradossi N, Saif, YM. Infections Bursal Disease. In: Swayne DE (ed) Diseases of Poultry, $13^{\text {th }}$ ed. Wiley-Blackwell, Ames; 2013.

2. Ferrero D, Garriga D, Navarro A, Rodríguez JF, Verdaguer N. Infectious bursal disease virus $V P 3$ upregulates VP1-mediated RNAdependent RNA replication. J Virol. 2015;89(21): 11165-8.

3. Wu H, Shi L, Zhang Y, Peng X, Zheng T, Li Y, et al . Ubiquitination is essential for avibirna virus replication by supporting $V P 1$ polymerase activity. J virol. 2019; 93(3): e01899-18.

4. Le XTK, Doan HTT, Do RT, Le TH. Molecular characterization of field isolates of infectious bursal disease virus from three decades, 19872018, reveals a distinct genotypic subgroup in Vietnam. Arch Virol. 2019;1-9.

5. Wang W, Song Y, Liu L, Zhang Y, Wang T, Zhang $\mathrm{W}$, et al. Neutralizing antibody mediated protection of chickens against infectious bursal disease via one-time vaccination with inactivated recombinant Lactococcus lactis expressing a fusion protein constructed from the RCK protein of Salmonella enterica and VP2 of infectious bursal disease virus. Microb. Cell Fact. 2019;18(1): 21

6. Luque D, Saugar I, Rejas MT, Carrascosa JL, Rodríguez JF, Castón JR. Infectious bursal disease virus: ribonucleoprotein complexes of a double-stranded RNA virus. J M Biol. 2009;386(3): 891-901.

7. Lee $\mathrm{CC}, \mathrm{Wu} \mathrm{CC}$, Lin TL. Chicken melanoma differentiation-associated gene 5 (MDA5) recognizes infectious bursal disease virus infection and triggers MDA5-related innate immunity. Arch Virol. 2014;159(7): 1671-86.

8. Lejal N, Da-Costa B, Huet JC, Delmas B. Role of Ser-652 and Lys-692 in the protease activity of infectious bursal disease virus VP4 and identification of its substrate cleavage sites. J Gen Virol. 2000;81(4): 983-92.

9. Méndez F, Romero N, Cubas LL, Delgui LR, Rodríguez D, Rodríguez JF. Non-lytic egression of infectious bursal disease virus (IBDV) particles from infected cells. PloS one. 2017;12(1):e0170080.

10. Li Z, Wang Y, Xue Y, Li X, Cao H, Zheng SJ. Critical role for voltage-dependent anion channel 2 in infectious bursal disease virusinduced apoptosis in host cells via interaction with VP5. J virol. 2012;86(3):1328-38.

11. Li K, Courtillon C, Guionie O, Allée C, Amelot $\mathrm{M}$, Qi X, et al. Genetic, antigenic and pathogenic characterization of four infectious bursal disease virus isolates from China suggests continued evolution of very virulent viruses. Infec Genet Evol. 2015;30: 120-7.

12. Pikuła A, Domańska BK, Cepulis R, Śmietanka $K$. Identification of infectious bursal disease virus with atypical VP2 amino acid profile in Latvia. J Vet Res. 2017;61(2): 145-9. 
13. Jackwood DJ, Sommer WSE, Crossley BM, Stoute ST, Woolcock PR, Charlton BR. Identification and pathogenicity of a natural reassortant between a very virulent serotype 1 infectious bursal disease virus (IBDV) and a serotype 2 IBDV. Virol. 2011;420(2): 98-105.

14. Abed M, Soubies S, Courtillon C, Briand FX, Allée C, Amelot M, et al. Infectious bursal disease virus in Algeria: Detection of highly pathogenic reassortant viruses. Infect, Genet Evol.2018;60: 48-57.

15. Soubies SM, Courtillon C, Briand FX, Queguiner-Leroux M, Courtois D, Amelot M, et al. Identification of a European interserotypicreassortant strain of infectious bursal disease virus. Avian Pathol. 2017;46(1): 19-27.

16. Pikuła A, Lisowska A, Jasik A, Śmietanka K. Identification and assessment of virulence of a natural reassortant of infectious bursal disease virus. J Vet Res. 2018; 49(1):89.

17. Yousif NK. Isolation and study of Gumboro virus in Iraq [Thesis]. Baghdad, Iraq, University of Baghdad; 1995.

18. Nawzad AR, Nahla MS, Shilan FM, Zana HM. Detection and Identification of Infectious Bursal Disease Virus in Broiler Farms in Sulaimani Province. Intl Journal of Adv in ChemEng and Biol Sci (IJACEBS). 2016;3(1):39-43.

19. Mohammed MH, Ali BH, Hasan II. Molecular characterization of local isolation of infectious bursal disease virus from broiler chickens in Iraq. Malays Appl Biol. 2015;43(2): 97-103.

20. Al-Zuhariy MTB, Rabee RHS, Abdulmaged $\mathrm{SH}$, Al-Baldawi AAA. Molecular Genotyping of Infectious Bursal Disease virus (IBDV) isolated from layer Flocks in Iraq. Al-Anbar J. Vet. Sci. 2016;(2): 100-9.

21. Caston JR, Rodriguez JF, Carrascosa JL. Infectious Bursal Disease Virus (IBDV) segmented double stranded RNA viruses: Structure and Molecular Biology.
2008;355-400.

22. Zierenberg K, Nieper H, Van den Berg TP, Ezeokoli CD, Voss M, Müller $\mathrm{H}$. The VP2 variable region of African and German isolates of infectious bursal disease virus: comparison with very virulent, classical, virulent, and attenuated tissue culture-adapted strains. Arch Virol. 2000;145(1): 113-25.

23. He X, Wei P, Yang X, Guan D, Wang G, Qin A. Molecular epidemiology of infectious bursal disease viruses isolated from Southern China during the years 2000-2010. Virus Genes. 2012;45(2): 246-55.

24. Ebersberger I, Metzler D, Schwarz C, Pääbo S. Genomewide comparison of DNA sequences between humans and chimpanzees. Am J Hum Genet. 2002;70(6): 1490-7.

25. Cristina J. The Ecological Role of Microorganisms in the Antarctic Environment, switsland Springer, Cham, 2019. Chapter9., Molecular Biology of RNA Viruses Isolated in Antarctica; P.197-217.

26. Zhou T, Ko EA, Gu W, Lim I, Bang H, Ko JH. Non-silent story on synonymous sites in voltage-gated ion channel genes. Plos One. 2012;7(10): 485.

27. Shi L, Li H, Ma G, Zhou J, Hong L, Zheng X, et al . Competitive replication of different genotypes of infectious bursal disease virus on chicken embryo fibroblasts. Virus Genes. 2009;39(1): 46-52.

28. Yilmaz A, Turan N, Bayraktar E, Gurel A, Cizmecigil UY, Aydin O, et al. Phylogeny and evolution of infectious bursal disease virus circulating in Turkish broiler flocks. J Poult Sci. 2019;98(5): 1976-84.

29. Rudd MF, Heine HG, Sapats SI, Parede L, Ignjatovic J. Characterisation of an Indonesian very virulent strain of infectious bursal disease virus. Arch Virol. 2002; 147:1303-1322. 


\section{التحليل الجيني للعزلات العقلية لقايروس لمرض الجراب الفايبريشي المعدي في الحقول العراقية 1رواء صلاح الدين جمعه ، 1عايدة برع علاوي ، 2رباح جبار}

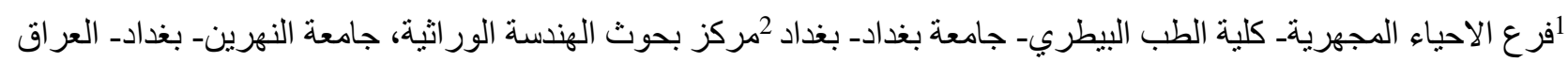

\section{الخلاصة}

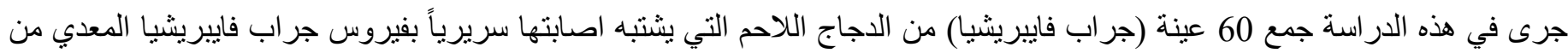

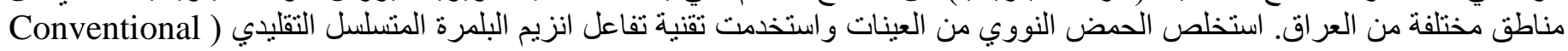

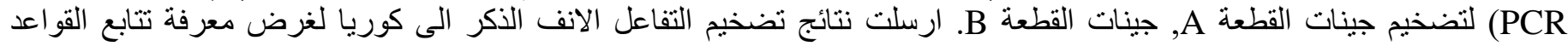

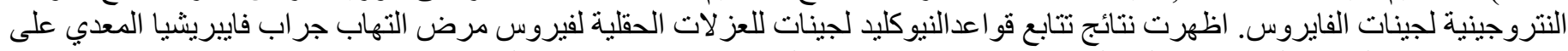

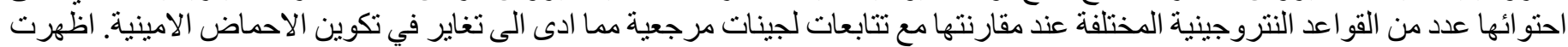

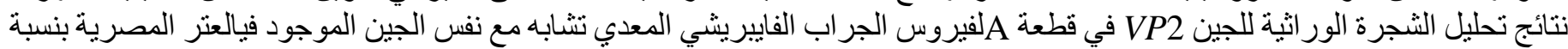

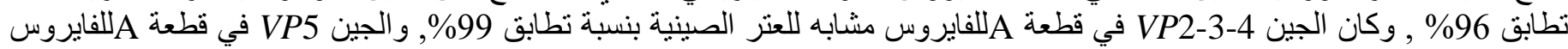

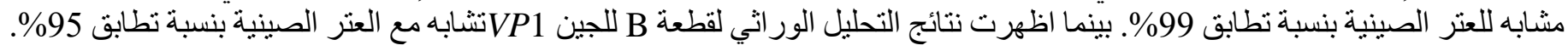

الكلمات المفتاحية:فيروس جراب فاييريشيا المعدي, تفاعل انزيم البلمرة التقليدي, تحليل التسلسل جينات VP, العراق 